\title{
Evidence for an extensive hydrothermal plume in the Tonga-Fiji region of the South Pacific
}

\author{
John E. Lupton \\ NOAA Pacific Marine Environmental Laboratory, Hatfield Marine Science Center, Newport, Oregon 97365, USA \\ (jobn.e.lupton@noaa.gov) \\ Douglas G. Pyle \\ College of Oceanic and Atmospheric Sciences, Oregon State University, Corvallis, Oregon 97331, USA \\ (pyled@hawaii.edu)
}

Now at Department of Geology and Geophysics, SOEST, Universityof Hawaii, Honolulu, Hawaii 96822, USA

\section{William J. Jenkins}

Chemistry Department, Woods Hole Oceanographic Institution, Woods Hole, Massachusetts 02543, USA

(wjenkins@whoi.edu)

\section{Ronald Greene and Leigh Evans \\ NOAA Pacific Marine Environmental Laboratory, Hatfield Marine Science Center, Newport, Oregon 97365, USA (ronald.r.greene@noaa.gov; leigh.j.evans@noaa.gov)}

[1] Several hydrographic stations in the vicinity of the Samoa Islands have ${ }^{3} \mathrm{He} /{ }^{4} \mathrm{He}$ above the regional background in the depth range of $1500-1800 \mathrm{~m}$, indicating injection of mantle helium from a local hydrothermal source. The highest $\delta\left({ }^{3} \mathrm{He}\right)=43.4 \%$ was detected at $1726-\mathrm{m}$ depth at $15.0^{\circ} \mathrm{S}, 173.1^{\circ} \mathrm{W}$ in the bathymetric gap between the Samoa Islands and the northern end of the Tonga-Kermadec Arc. The $\delta\left({ }^{3} \mathrm{He}\right)$ profile at this station decreases to $\delta\left({ }^{3} \mathrm{He}\right)=26 \%$ at $2500-\mathrm{m}$ depth. The relatively shallow depth of the maximum hydrothermal signal suggests a source different from the conventional Pacific basin helium plume centered at $2500 \mathrm{~m}$ that is carried westward from the East Pacific Rise. Stations to the west of this locality show a progressive decrease in the maximum $\delta\left({ }^{3} \mathrm{He}\right)$ values in the depth range of $1480-1790 \mathrm{~m}$ out to $169^{\circ} \mathrm{E}$. Stations east of the Tonga-Fiji region show lower ${ }^{3} \mathrm{He}$ values $(<26 \%)$ at $1700 \mathrm{~m}$ and the profiles are dominated by a deeper maximum at $2500 \mathrm{~m}$, presumably the distal traces of hydrothermal input from East Pacific Rise. This pattern in the ${ }^{3} \mathrm{He}$ distribution suggests that the 1700 -m deep helium plume is carried in a northwesterly direction some $2000 \mathrm{~km}$ from its source near the northern end of the Tonga-Kermadec Arc. At this time very little is known about the source of this hydrothermal plume or the details of its areal extent. Numerous seamounts and rift zones in the region are possible hydrothermal sources for the plume. The summit crater of Vailulu'u, a young seamount at the eastern end of the Samoa chain, was recently discovered to be hydrothermally active at $\sim 600 \mathrm{~m}$ depth [Hart et al., 2000]. However this shallow hydrothermal field on Vailulu'u is an unlikely source for the deeper 1700-m signal. The most likely source would appear to be the extensional zones of the northern Lau Basin system, such as the Mangatolo Triple Junction. Just as the helium plume emanating from Lo'ihi has helped our understanding of the circulation near the Hawaiian Islands [Lupton, 1996], this helium plume in the Tonga-Fiji region has great potential for delineating circulation in this area of the south Pacific.

Components: 7879 words, 12 figures.

Keywords: Hydrothermal; helium; Pacific; Tonga; circulation; kermadec. 
Index Terms: 9355 Information Related to Geographic Region: Pacific Ocean; 4832 Oceanography: Biological and Chemical: Hydrothermal systems; 4512 Oceanography: Physical: Currents.

Received 23 July 2003; Revised 3 November 2003; Accepted 4 November 2003; Published 17 January 2004.

Lupton, J. E., D. G. Pyle, W. J. Jenkins, R. Greene, and L. Evans (2004), Evidence for an extensive hydrothermal plume in the Tonga-Fiji region of the South Pacific, Geochem. Geophys. Geosyst., 5, Q01003, doi:10.1029/2003GC000607.

\section{Introduction}

[2] The discovery by Clarke et al. [1969] of excess ${ }^{3} \mathrm{He}$ in the Pacific Ocean initiated a new chapter in tracer oceanography involving the use of ${ }^{3} \mathrm{He}$ to map patterns of deep ocean circulation and mixing. Subsequent studies of helium isotopes in samples of deep seawater and in oceanic volcanic rocks demonstrated that helium highly enriched in ${ }^{3} \mathrm{He}$ is released into the deep oceans by hydrothermal activity associated with seafloor volcanism [Krylov et al., 1974; Lupton and Craig, 1975; Lupton et al., 1977; Jenkins et al., 1978]. Helium is a particularly useful tracer for ocean circulation studies because it is stable, conservative, and has relatively simple boundary conditions. While most of the excess ${ }^{3} \mathrm{He}$ found in the deep ocean is introduced at active midocean ridge spreading centers [Lupton, 1998], recently helium plumes have been observed emanating from hot spot volcanoes such as Lo'ihi Seamount [Lupton, 1996] and from active arc volcanoes in the south Pacific [de Ronde et al., 2001].

[3] In this paper we report the discovery of an extensive helium plume centered at $\sim 1750-\mathrm{m}$ depth in the vicinity of the Samoa Islands. Although the source of the plume is not known, it is too shallow to have originated on a typical mid-ocean ridge spreading center such as the East Pacific Rise (EPR) or the Pacific-Antarctic Ridge (PAR). In the pages that follow we will first describe what we know about the areal extent of the plume and then discuss possible sources that may have produced the plume. We argue that this plume merits further study. If the plume source were identified, the plume distribution would have great value for mapping the deep circulation and mixing in this region of the south Pacific.

\section{Results}

[4] The first indication of the existence of the "Tonga-Fiji plume" came from hydrographic profiles collected on NOAA's TEW (Transport of Equatorial Waters) Expedition that spanned the Pacific in a long zonal section at latitude $15^{\circ} \mathrm{S}$ (Figure 1) [Mangum et al., 1991; Wisegarver et al., 1993]. Samples were collected at 25 stations and later analyzed for helium concentration $\left({ }^{4} \mathrm{He}\right)$ and helium isotope ratio $\left({ }^{3} \mathrm{He} /{ }^{4} \mathrm{He}\right)$. The strongest plume signal was found at TEW Station 39 (at $\left.15.0^{\circ} \mathrm{S}, 173.1^{\circ} \mathrm{W}\right)$, where the ${ }^{3} \mathrm{He} /{ }^{4} \mathrm{He}$ ratio reached a maximum of $\delta\left({ }^{3} \mathrm{He}\right)=43.4 \%$ at a depth of $1726 \mathrm{~m}$ (Figure 2). This station was located about $150 \mathrm{~km}$ southwest of Savai'i, Western Samoa, in the bathymetric gap between the Samoa Islands and the northern end of the Tonga-Kermadec Arc. A second profile $650 \mathrm{~km}$ farther west at TEW Station $46\left(14.9^{\circ} \mathrm{S}, 179.0^{\circ} \mathrm{W}\right)$ had a similar ${ }^{3} \mathrm{He}$ enrichment of $\delta\left({ }^{3} \mathrm{He}\right)=41.2 \%$ at a slightly shallower depth of $1480 \mathrm{~m}$ (Figure 2).

[5] The discovery of such high ${ }^{3} \mathrm{He}$ concentrations in this region of the south Pacific is surprising since this locality is remote from any typical midocean ridge spreading centers that have similar ${ }^{3} \mathrm{He}$ signals. The closest active ridges are the East Pacific Rise over $6000 \mathrm{~km}$ to the east, and the slower spreading Pacific-Antarctic Ridge about $5500 \mathrm{~km}$ to the south. On the basis of our knowledge of the basin-scale ${ }^{3} \mathrm{He}$ distribution in the Pacific, one would expect helium profiles in this region to reach a maximum of $\delta\left({ }^{3} \mathrm{He}\right) \approx 30 \%$ at $2500-\mathrm{m}$ depth in the absence of any local sources of helium injection. In particular, we would expect to find $\delta\left({ }^{3} \mathrm{He}\right) \leq 25 \%$ in this region at the shallower $1750-\mathrm{m}$ depth of the Tonga-Fiji plume. Thus the $\delta\left({ }^{3} \mathrm{He}\right)=43 \%$ we have observed in this region near the Samoa Islands represents a large excess com- 


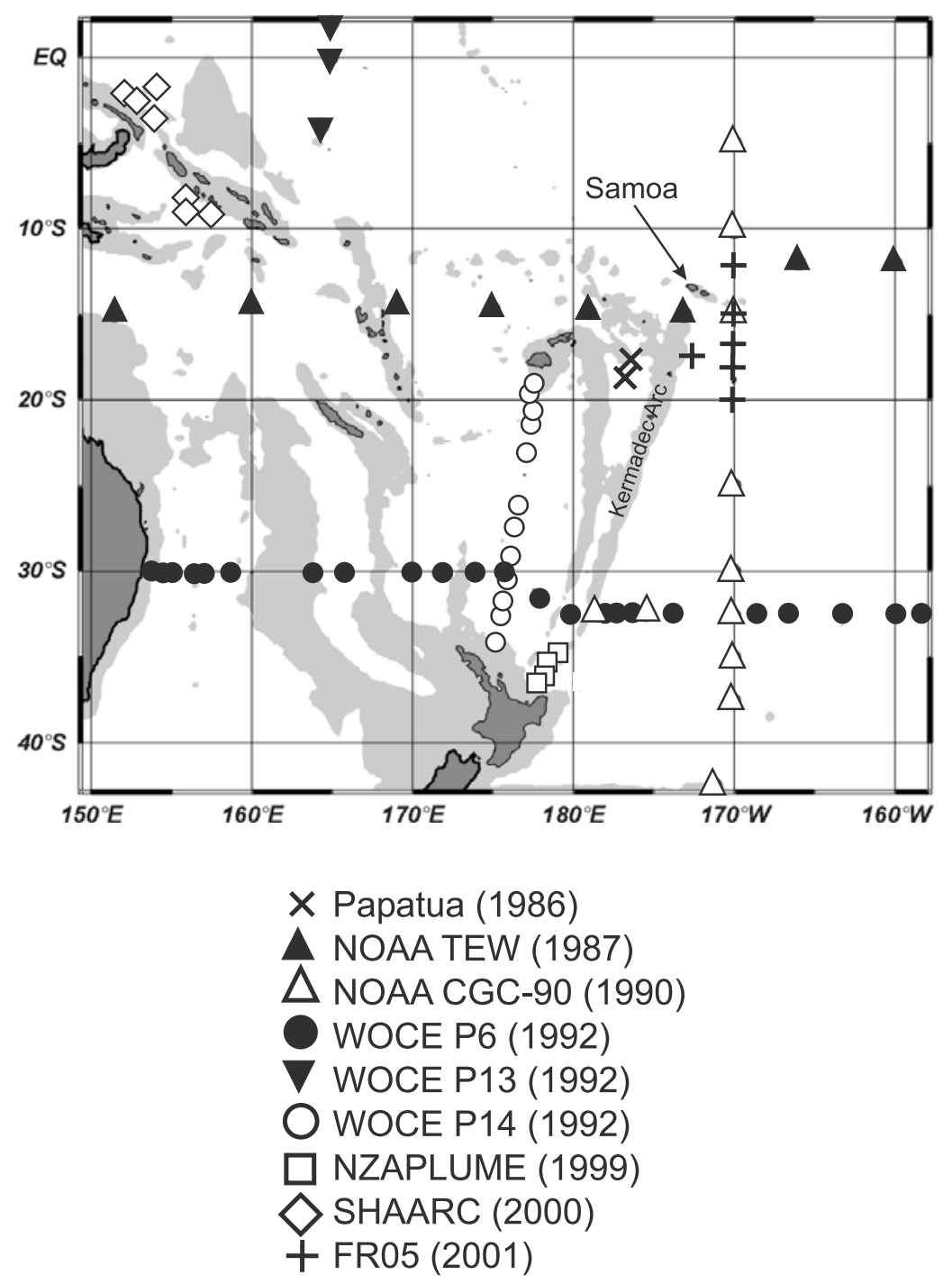

Figure 1. Map showing the station locations for the helium data used in this study. The data were collected on nine different expeditions from 1986 to 2001. The data for Papatua Expedition were provided by Harmon Craig, and for WOCE P6 by William Jenkins. All other measurements were made in the Helium Isotope Laboratory, NOAA PMEL, Newport, Oregon.

pared to the expected helium signals from the distant mid-ocean ridges.

[6] Examination of the entire helium section along the TEW Expedition track demonstrates that the Tonga-Fiji hydrothermal plume is quite distinct from the larger and deeper helium plume generated on the crest of the East Pacific Rise. Figure 3 shows $\delta\left({ }^{3} \mathrm{He}\right)$ contoured in section view for the long TEW zonal section at $15^{\circ} \mathrm{S}$. The helium plume originating from the EPR reaches values of $\delta\left({ }^{3} \mathrm{He}\right)=40 \%$ at $2500-\mathrm{m}$ depth directly over the ridge crest at longitude $115^{\circ} \mathrm{W}$. The EPR plume is carried westward from the ridge axis by the deep currents. At the distal end of the plume near the Tonga Arc at $170^{\circ} \mathrm{W}$, mixing and dilution have reduced the helium signal to $\delta\left({ }^{3} \mathrm{He}\right) \leq 30 \%$. In the same vicinity, the Tonga-Fiji plume appears as a strong secondary helium signal centered some $800 \mathrm{~m}$ shallower than the deeper EPR plume. Like 

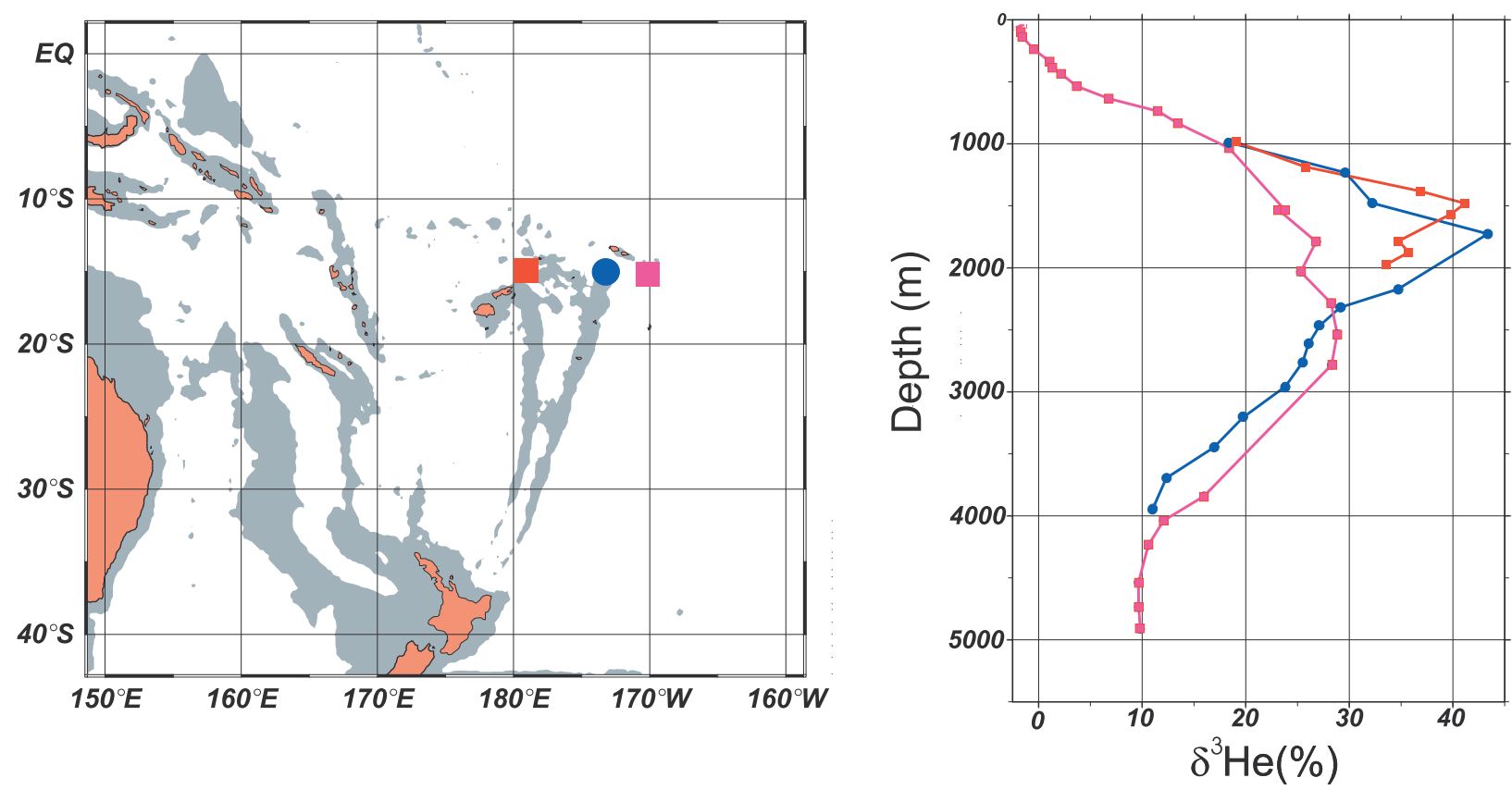

Figure 2. Profiles of ${ }^{3} \mathrm{He} /{ }^{4} \mathrm{He}$ from 3 stations forming a short east-west section in the Tonga-Fiji region of the south Pacific. Here the ${ }^{3} \mathrm{He} /{ }^{4} \mathrm{He}$ ratio is expressed as $\delta^{3} \mathrm{He}$, which is the percentage deviation of the ${ }^{3} \mathrm{He} /{ }^{4} \mathrm{He}$ ratio from the ratio in air. Thus $\delta^{3} \mathrm{He}=100\left[\left(\mathrm{R} / \mathrm{R}_{\text {air }}\right)-1\right]$, where $\mathrm{R}={ }^{3} \mathrm{He} /{ }^{4} \mathrm{He}$ of the measured sample and $\mathrm{R}_{\text {air }}=\left({ }^{3} \mathrm{He} /{ }^{4} \mathrm{He}\right)_{\text {air }}=$ $1.39 \times 10^{-6}$. The two profiles from TEW expedition show a strong helium plume signal at depths of 1400 to $1800 \mathrm{~m}$, while the CGC-90 profile farther east shows only background helium levels. The TEW and CGC-90 samples were collected in 1987 and 1990, respectively.

the EPR plume, the Tonga-Fiji plume signal also appears to be carried westward by the deep circulation, although possibly confined to a much smaller area by the regional bathymetry. It is interesting to note that the northward intrusion of circumpolar water into the Pacific basin can be seen as a ${ }^{3} \mathrm{He}$-depleted water mass $\left(\delta\left({ }^{3} \mathrm{He}\right) \leq\right.$ $14 \%$ ) below $3500-\mathrm{m}$ depth at $160-175^{\circ} \mathrm{W}$ (Figure 3).

[7] The Tonga-Fiji plume has a very clear expression at TEW Stations 39 and 46. However the question remains whether the plume can be detected in any other hydrographic profiles. Figure 4 compares the TEW Station 39 and Station 46 profiles with some other profiles we have analyzed in the region. It is immediately apparent that the profiles to the east of the Samoa Islands have a completely different character compared to profiles to the west. To the east the ${ }^{3} \mathrm{He}$ profiles increase smoothly to a maximum of $\delta\left({ }^{3} \mathrm{He}\right) \approx 30 \%$ at $\sim 2500-\mathrm{m}$ depth, corresponding to the depth of the core of the EPR plume (Figure 4c). Further- more, none of the profiles to the east of Samoa show significant excess ${ }^{3} \mathrm{He}$ in the $1400-1800 \mathrm{~m}$ depth range where one might expect the TongaFiji plume to appear. Thus the $\delta\left({ }^{3} \mathrm{He}\right)$ profiles to the east are dominated by Pacific basin mid-ocean ridge helium from the EPR and possibly the PAR. In contrast, the ${ }^{3} \mathrm{He}$ profiles to the west of the Samoa Islands increase more rapidly with depth and reach a maximum of $\delta\left({ }^{3} \mathrm{He}\right)=22-29 \%$ at a depth of $\sim 1750 \mathrm{~m}$. Furthermore, the profiles to the west do not display a secondary maximum in the 2500-m depth range that characterizes the plume signal originating from mid-ocean ridge activity (Figure 4a). Surprisingly, profiles like those in Figure $4 \mathrm{a}$ are found as far west as the Coral Sea at $153^{\circ} \mathrm{E}, \sim 3800 \mathrm{~km}$ west of Samoa. These observations suggest that the Tonga-Fiji plume, or a similar shallow helium source, exerts a strong influence on the helium profiles throughout a broad region of the southwestern Pacific.

[8] We have constructed a contour map of $\delta\left({ }^{3} \mathrm{He}\right)$ at $1750-\mathrm{m}$ depth in the region surrounding the 


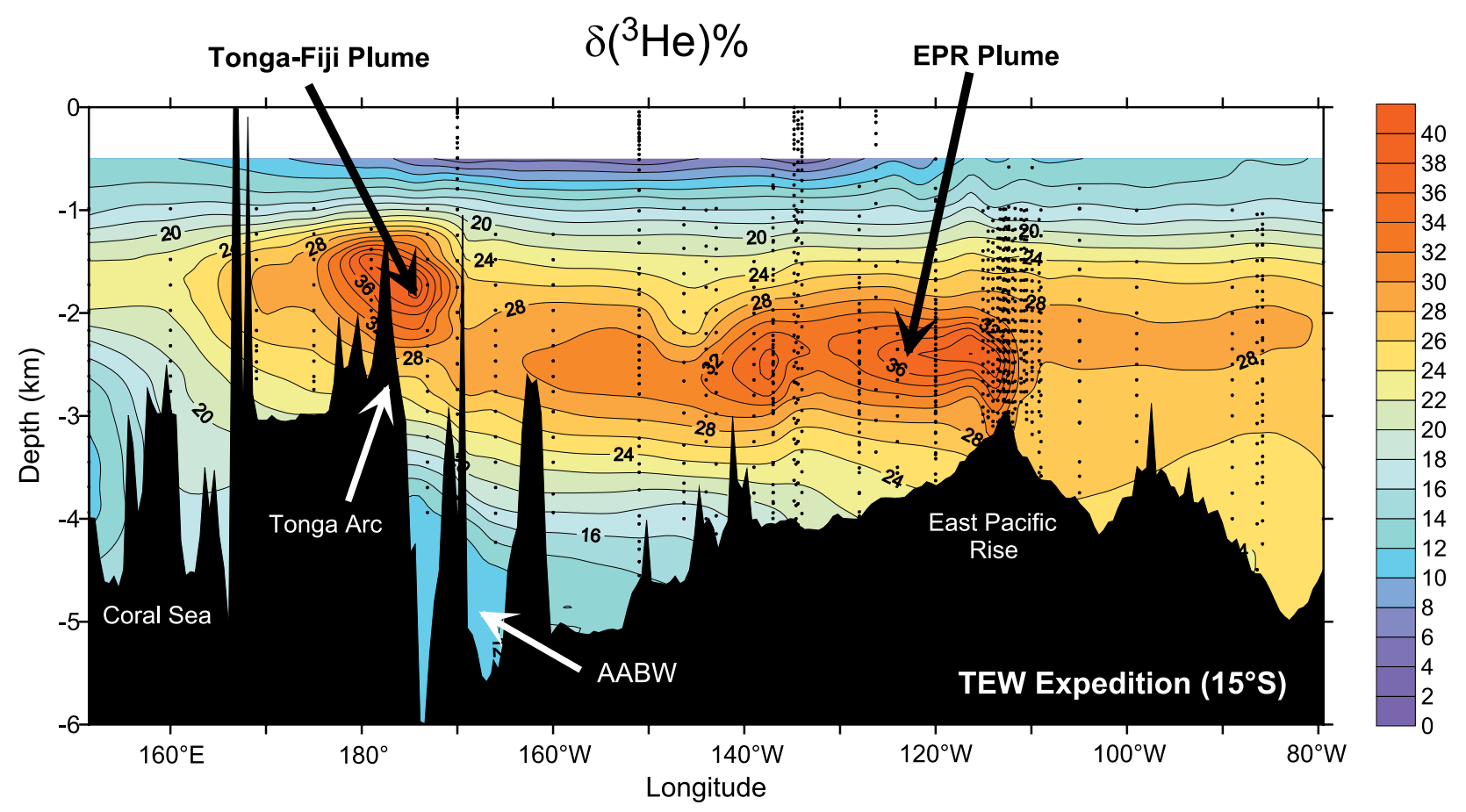

Figure 3. A long zonal $\delta^{3} \mathrm{He}$ section contoured in section view spanning the Pacific at latitude $15^{\circ} \mathrm{S}$. Most of the samples are from TEW expedition, although a few samples from other expeditions are included at $135^{\circ} \mathrm{W}$ and at $112^{\circ} \mathrm{W}$. The section shows two distinct ${ }^{3} \mathrm{He}$ plumes, one situated at $2500-\mathrm{m}$ depth emanating from the EPR crest and a second shallower plume in the Tonga-Fiji region. The apparent location of the tongue of Antarctic Bottom Water is labeled $\mathrm{AABW}$ in the figure.

Samoa Islands and the northern end of the TongaKermadec Arc to ascertain the areal extent and possible sources of the Tonga-Fiji hydrothermal plume. The discrete $\delta\left({ }^{3} \mathrm{He}\right)$ values from the individual bottles from each hydrographic profile were first interpolated onto a $1750-\mathrm{m}$ depth surface (Figure 5a), and then those interpolated values were contoured in map view (Figure 5b). Although the areal coverage is relatively good along $30^{\circ} \mathrm{S}$, the ${ }^{3} \mathrm{He}$ data are rather sparse in the Tonga-Fiji region. Nonetheless, the $1750-\mathrm{m}$ data show the presence of a distinct ${ }^{3} \mathrm{He}$ plume with its core centered just southwest of the Samoa Islands. The plume exhibits a high degree of asymmetry: the signal is truncated abruptly to the east and extends a considerable distance to the west. More specifically, the plume appears to trend in a northwesterly direction away from the Samoa Islands and is evident out to longitude $160^{\circ} \mathrm{E}$.

[9] This $\delta\left({ }^{3} \mathrm{He}\right)$ contour map combines data from several expeditions carried out from 1987 to 2001
(Figure 1), resulting in the most comprehensive coverage available to date. Although the data set is not synoptic, the 14-year interval represented by the data is relatively short compared to the timescale for plume dispersal at this depth. Furthermore, the extent of the plume is mainly defined by hydrocasts collected in a 5-year period between 1987 and 1992, as shown in Figure 1.

[10] One way to test the possibility of temporal variability of the ${ }^{3} \mathrm{He}$ data set is to compare $\delta\left({ }^{3} \mathrm{He}\right)$ profiles collected at the same station location at different times. In 2001, we were able to re-occupy a station location at $15^{\circ} \mathrm{S}, 170^{\circ} \mathrm{W}$ where a ${ }^{3} \mathrm{He}$ profile had been collected 11 years earlier during CGC-90 expedition. A comparison of these two $\delta\left({ }^{3} \mathrm{He}\right)$ profiles (Figure 6) shows that no appreciable change has occurred in the ${ }^{3} \mathrm{He}$ profile during the last 11 years. This suggests that deep ocean ${ }^{3} \mathrm{He}$ concentrations change very slowly, on decadal or longer timescales, and that it is valid to treat our data set as if it were synoptic. 

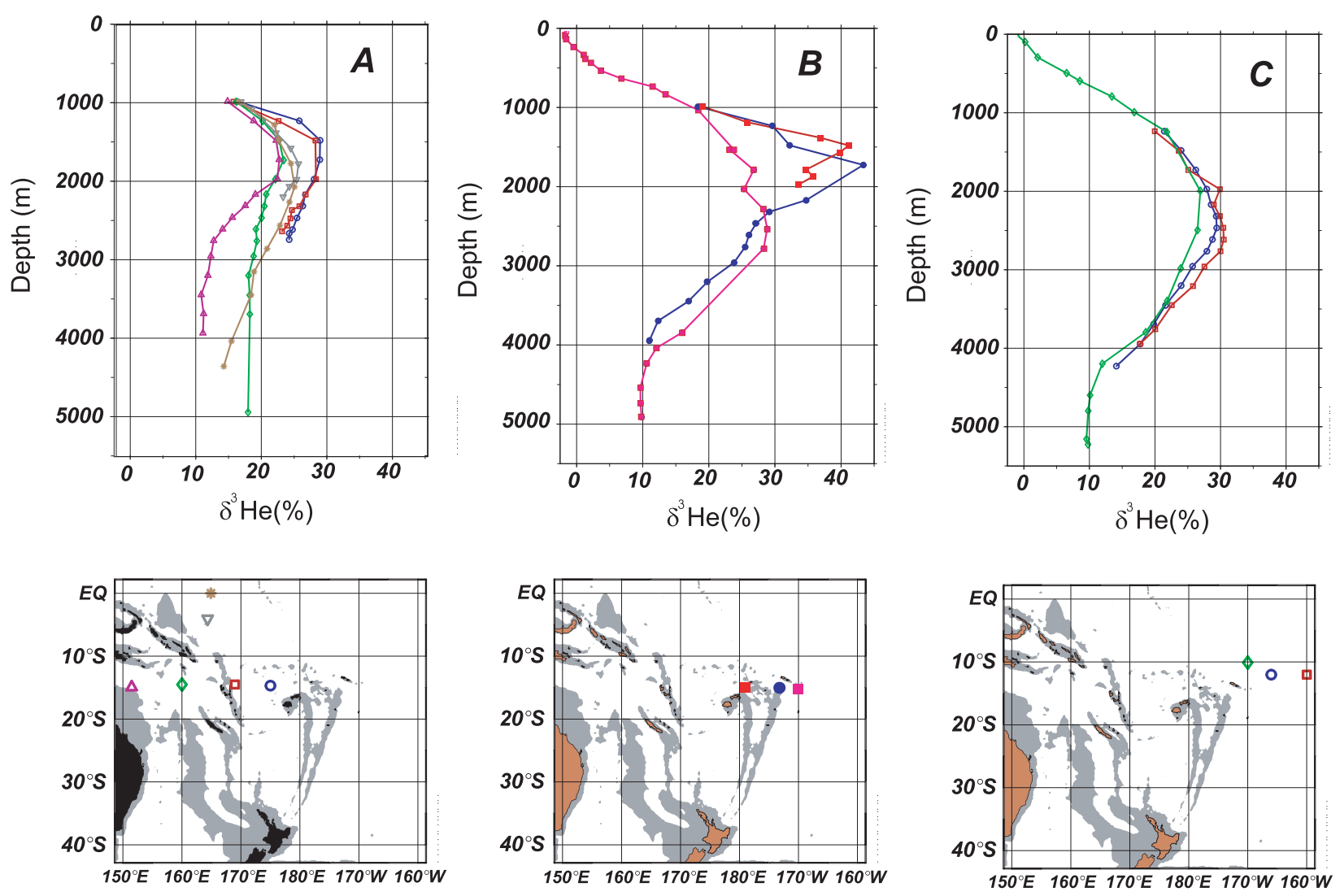

Figure 4. A comparison of $\delta^{3} \mathrm{He}$ profiles in different regions of the southwestern Pacific. (a) profiles to the west of the Tonga-Fiji region reach a maximum at 1500 to $1700-\mathrm{m}$ depth, (b) as shown in Figure 2, two profiles in the TongaFiji region show a very strong maximum in $\delta^{3} \mathrm{He}$ at 1500 to $1800-\mathrm{m}$ depth, and (c) profiles to the east of the TongaFiji region reach a broad maximum in $\delta^{3} \mathrm{He}$ at $2500-\mathrm{m}$ depth. The maps below each figure indicate the station locations.

[11] It is of interest to compare the distribution of the helium plume with the best estimates of the regional flow in this area of the Pacific. Reid [1997] has estimated the geostrophic flow on various depth surfaces by carefully examining the hydrographic data from several expeditions. As shown in Figure 7, Reid's maps at 1500-m and at 2000-m depth indicate a general northwesterly flow in the central south Pacific. When this flow encounters the topographic barrier of the Kermadec Arc, it splits into two branches. One branch continues in a westerly or northwesterly direction across the northern end of the Kermadec Arc; the other branch flows in a southerly direction along the eastern margin of the Kermadec Arc (Figure 7). This flow pattern is consistent with the shape and areal extent of the helium plume, in that the plume appears to be carried in a northwesterly direction away from an apparent point source in the TongaFiji-Samoa region. In addition, the southward flow indicated in Reid's maps is consistent with a secondary lobe in the $\delta\left({ }^{3} \mathrm{He}\right)$ distribution that extends southward along the $170^{\circ} \mathrm{W}$ meridian (see Figure 5b).

[12] While the Tonga-Fiji helium plume is clearly an impressive hydrothermal feature, the question remains as to its significance relative to the total hydrothermal input into the Pacific basin. Since ${ }^{3} \mathrm{He}$ is a stable conservative tracer, one way to address this is to examine the ${ }^{3} \mathrm{He}$ distribution at the basin scale. Armed with the knowledge that the oceans are stratified and that tracers injected at a given depth tend to be confined to that surface, we have chosen to examine the ${ }^{3} \mathrm{He}$ distribution on different surfaces of constant depth. Figure 8 shows 

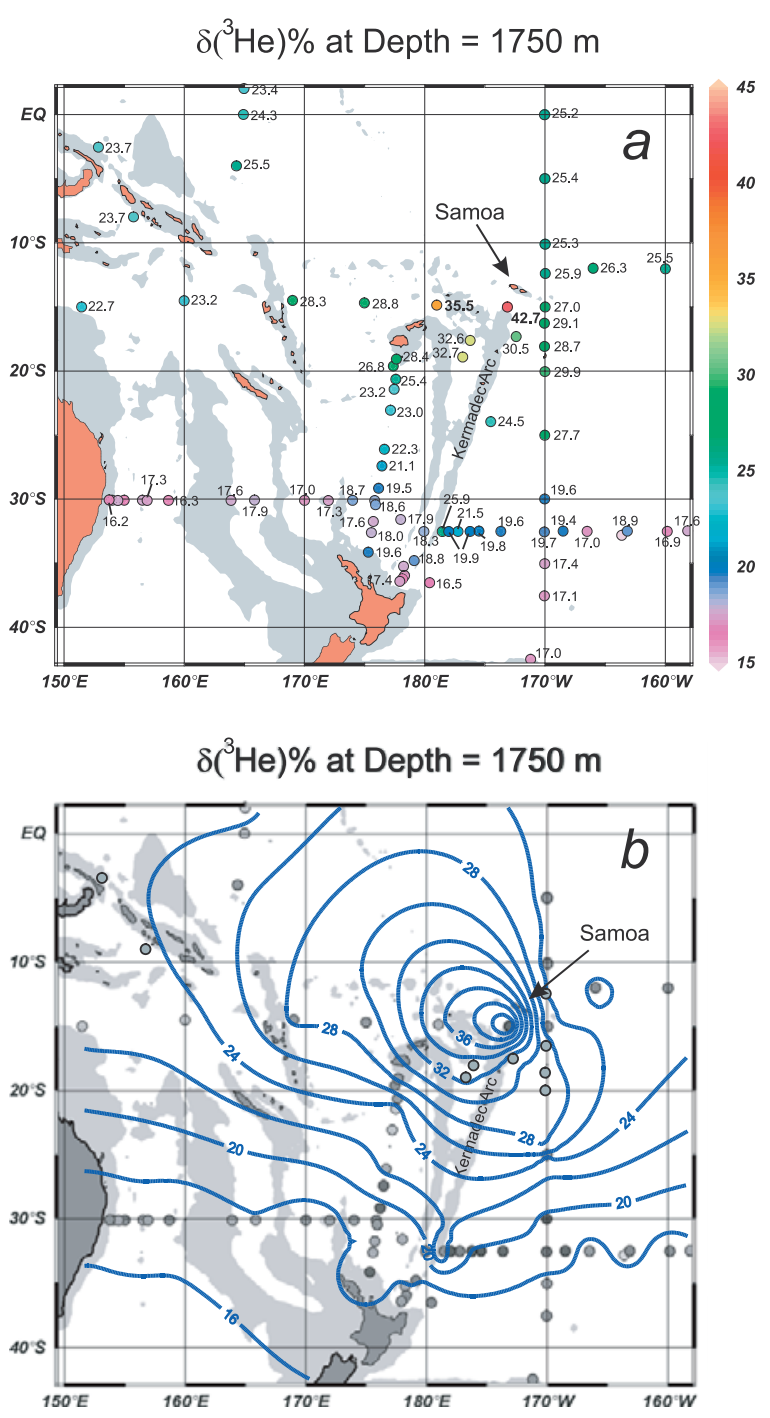

Figure 5. (a) ${ }^{3} \mathrm{He} /{ }^{4} \mathrm{He}$ ratios in the southwestern Pacific interpolated onto a surface at $1750-\mathrm{m}$ depth. Data are from the vertical stations shown in Figure 1. Small numbers are $\delta^{3} \mathrm{He}(\%)$ values. Color scale at the right denotes color coding of the $\delta^{3} \mathrm{He}$ values for each data point. (b) The same data contoured with contour interval of $2 \%$ in $\delta^{3} \mathrm{He}$.

the ${ }^{3} \mathrm{He}$ distribution for the entire Pacific contoured on surfaces at 1000-m and 1700-m depth. At 1000-m depth, the ${ }^{3} \mathrm{He}$ distribution is dominated by a plume originating on Lo'ihi Seamount on the southeastern flank of Hawaii. The Lo'ihi plume, as reported previously by Lupton [1996], is similar to the Tonga-Fiji plume discussed here since both plumes appear to originate from a point source. In contrast, plumes from mid-ocean ridge hydrother- mal activity are best approximated with line source injection.

[13] At $1700-\mathrm{m}$ depth, the Tonga-Fiji plume is a significant feature and is in fact the strongest hydrothermal helium signal in the entire Pacific basin. Notably, the Lo'ihi helium plume is completely absent at that depth and only a slight contribution from the combined ${ }^{3} \mathrm{He}$ injection along the mid-ocean ridge system is visible. Although it is difficult to quantify the hydrothermal flux associated with the Tonga-Fiji plume, analysis of the helium distribution suggests that this plume is a significant source even at the basin scale. As might be expected, at the $2500-\mathrm{m}$ depth of the crest of the mid-ocean ridge system, the ${ }^{3} \mathrm{He}$ field in the Pacific is dominated by plumes from the mid-ocean ridge system [see Lupton, 1998].

\section{The Source of the Plume}

[14] It is clear that the Tonga-Fiji plume has its origin somewhere near the Samoa Islands or at the

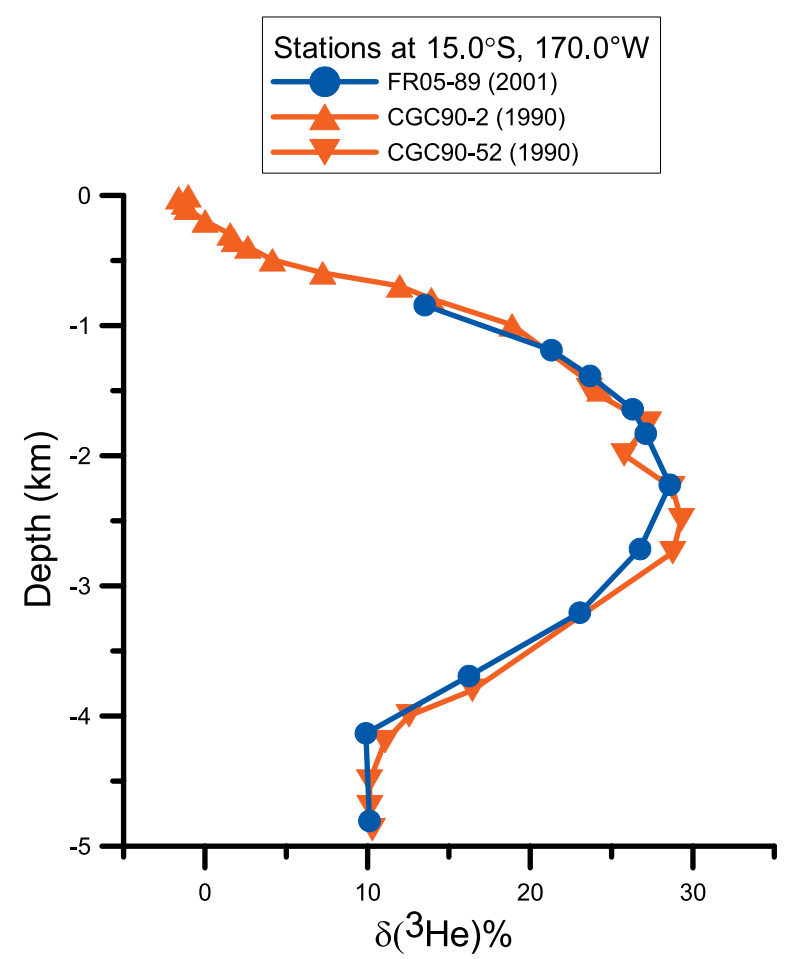

Figure 6. A comparison of two $\delta^{3} \mathrm{He}$ profiles collected 11 years apart at $15^{\circ} \mathrm{S}, 170^{\circ} \mathrm{W}$ near the Samoa Islands. We have combined stations 2 and 52 from expedition CGC-90 to form a single profile, since they were collected at the same location about 1 month apart. 

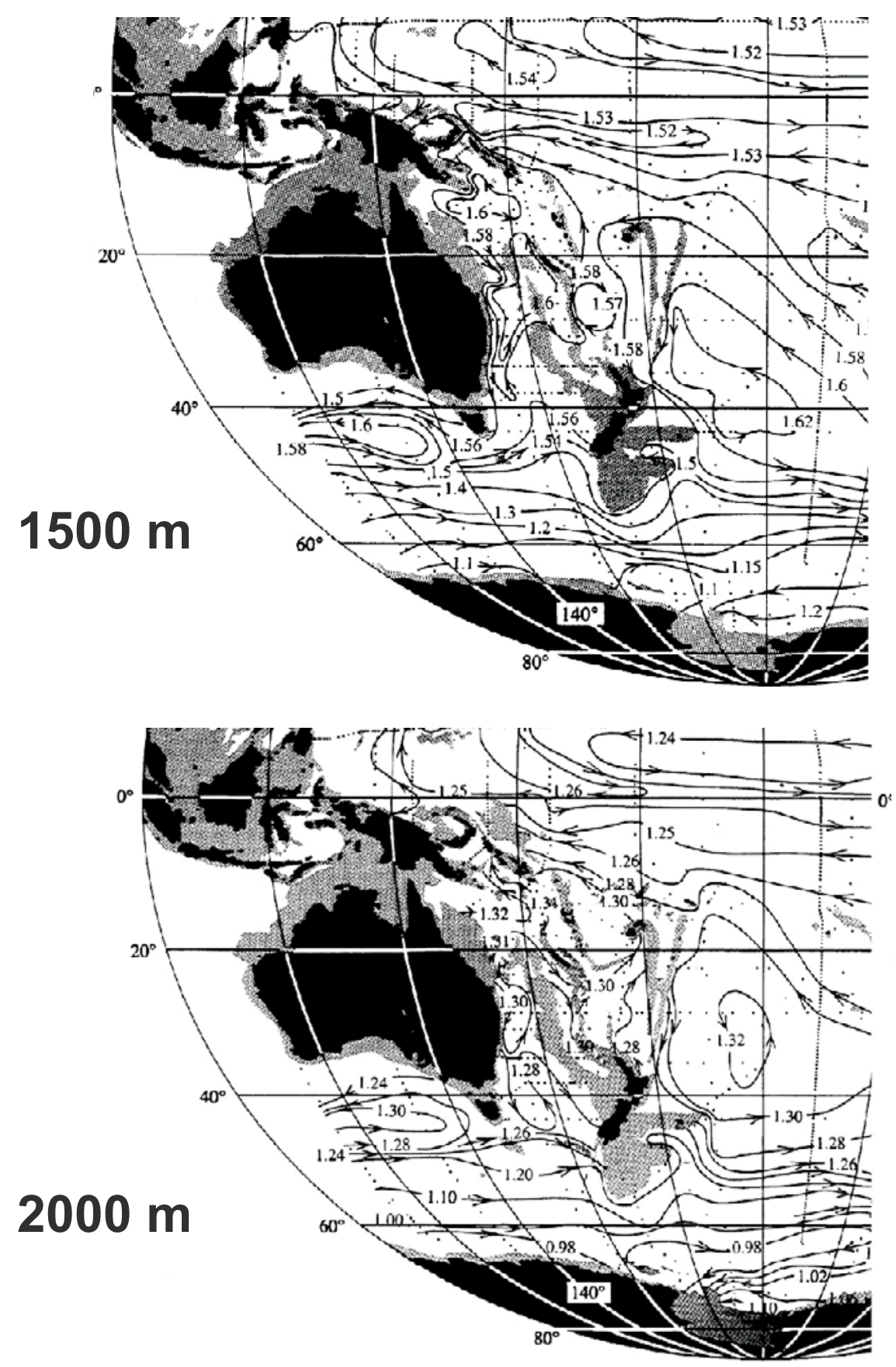

Figure 7. Adjusted steric height at $1500 \mathrm{dbar}$ and at $2000 \mathrm{dbar}$ in units of dynamic meters $\left(10 \mathrm{~m}^{2} \mathrm{~s}^{-2}\right)$. The arrows indicate the sense of the geostrophic flow at these two depths. Figures taken from Reid [1997] (reprinted with permission from Elsevier).

northern end of the Kermadec Arc - Lau Basin area. However the specific source of the helium plume is unknown. As discussed above, the relatively shallow depth of the Tonga-Fiji plume and its great distance from the East Pacific Rise and the Pacific-Antarctic Ridge indicate that hydrothermal venting along the mid-ocean ridge system is not the source. The fact that the maximum of the helium plume is at 1400 to $1800-\mathrm{m}$ depth places some constraints on possible sources, since ascending hydrothermal plumes typically rise 50 to $150 \mathrm{~m}$ before becoming neutrally buoyant and spreading laterally [Lupton, 1995]. This suggests that the hydrothermal source for the Tonga-Fiji plume is 
situated somewhere between 1450 and 1950-m depth, considerably shallower than the average global ridge crest depth of 2200-2500 m. While conventional mid-ocean ridge spreading centers such as the East Pacific Rise are an unlikely source for the Tonga-Fiji plume, there are several sites of
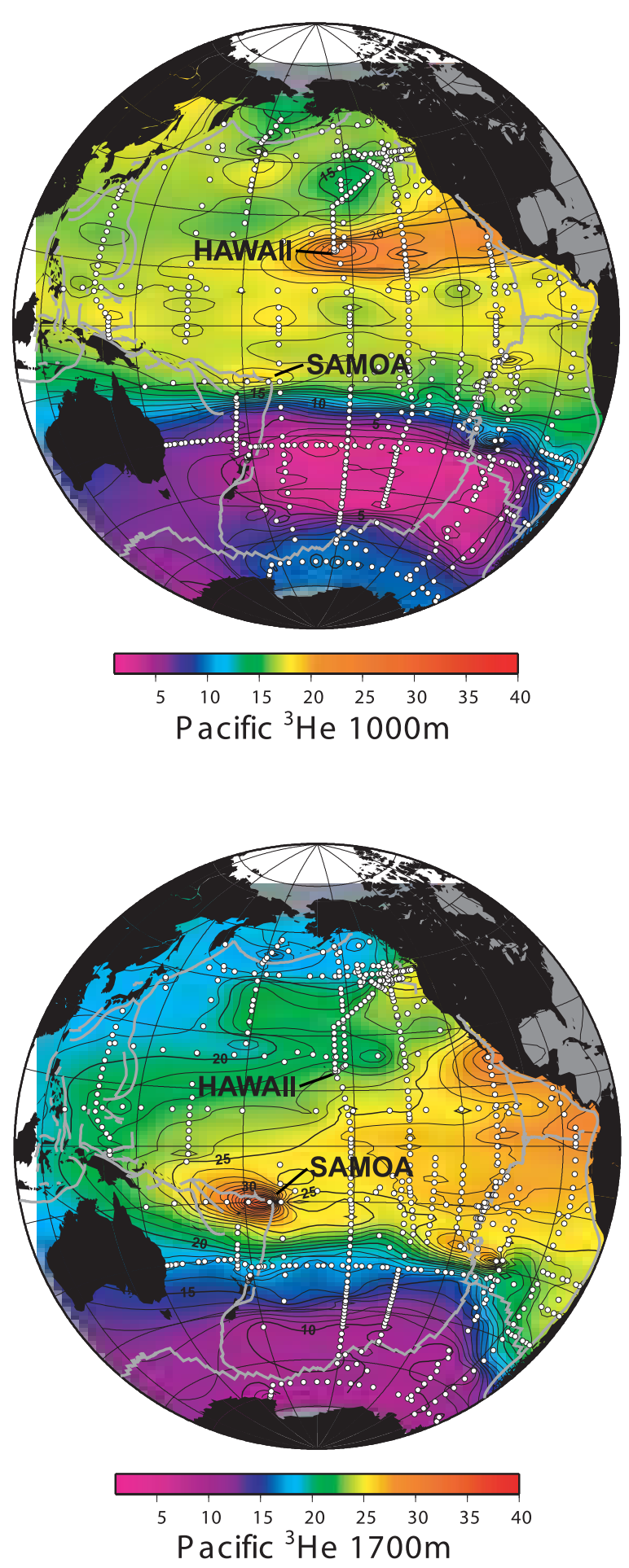

volcanic activity in the Tonga-Fiji region that may host active hydrothermal systems. These include the Samoa Islands, the volcanoes of the TongaKermadec Arc, and the Lau Basin and other back-arc spreading centers associated with the Tonga-Kermadec Arc system (see Figure 9).

\subsection{The Samoa Islands and Vailulu'u}

[15] The Samoa Islands are an active volcanic chain generally assumed to have been generated by the motion of the Pacific Plate over the Samoan hot spot, similar to the Hawaiian-Emperor Seamount chain [Clague and Dalrymple, 1989; Hart et al., 2000]. Although the lavas of the Samoa Islands have been studied in some detail [Farley et al., 1992; Farley and Neroda, 1998], relatively little is known about submarine hydrothermal activity associated with the islands or seamounts of the Samoa chain. Vailulu'u, a seamount located about $45 \mathrm{~km}$ east of Ta'u Island at the eastern end of the Samoa chain, is the probable present location of the mantle hotspot responsible for the Samoa Islands (see Figure 10). In this sense Vailulu'u is analogous to Lo'ihi Seamount, an active volcano situated on the southeastern flank of the Island of Hawaii and thought to be the current location of the Hawaiian hotspot.

[16] Vailulu'u is of particular interest for our plume study because Hart et al. [2000] recently reported evidence for hydrothermal activity within the summit caldera. Vailulu'u rises to a depth of $590 \mathrm{~m}$ at its shallowest point, and the summit has an ovalshaped crater that is $2 \mathrm{~km}$ wide and $400 \mathrm{~m}$ deep. The crater rim is breached to a depth of $780 \mathrm{~m}$ below sea level at two points, one on the northwest side and a second narrow breach on the southeast

Figure 8. Maps of $\delta^{3} \mathrm{He}$ at two different depths for the entire Pacific Basin. At $1000-\mathrm{m}$ depth, a strong ${ }^{3} \mathrm{He}$ plume originates on Lo'ihi Seamount in the northern Pacific and appears to propagate eastward toward the coast of Mexico. At 1700-m depth, the Lo'ihi plume is absent and the strongest ${ }^{3} \mathrm{He}$ signal is from the TongaFiji plume in the south Pacific. Note that the color scales for the two maps are different. The white dots represent the hydrographic stations used for the Pacific basin helium field, and the gray lines indicate the active plate boundaries. 


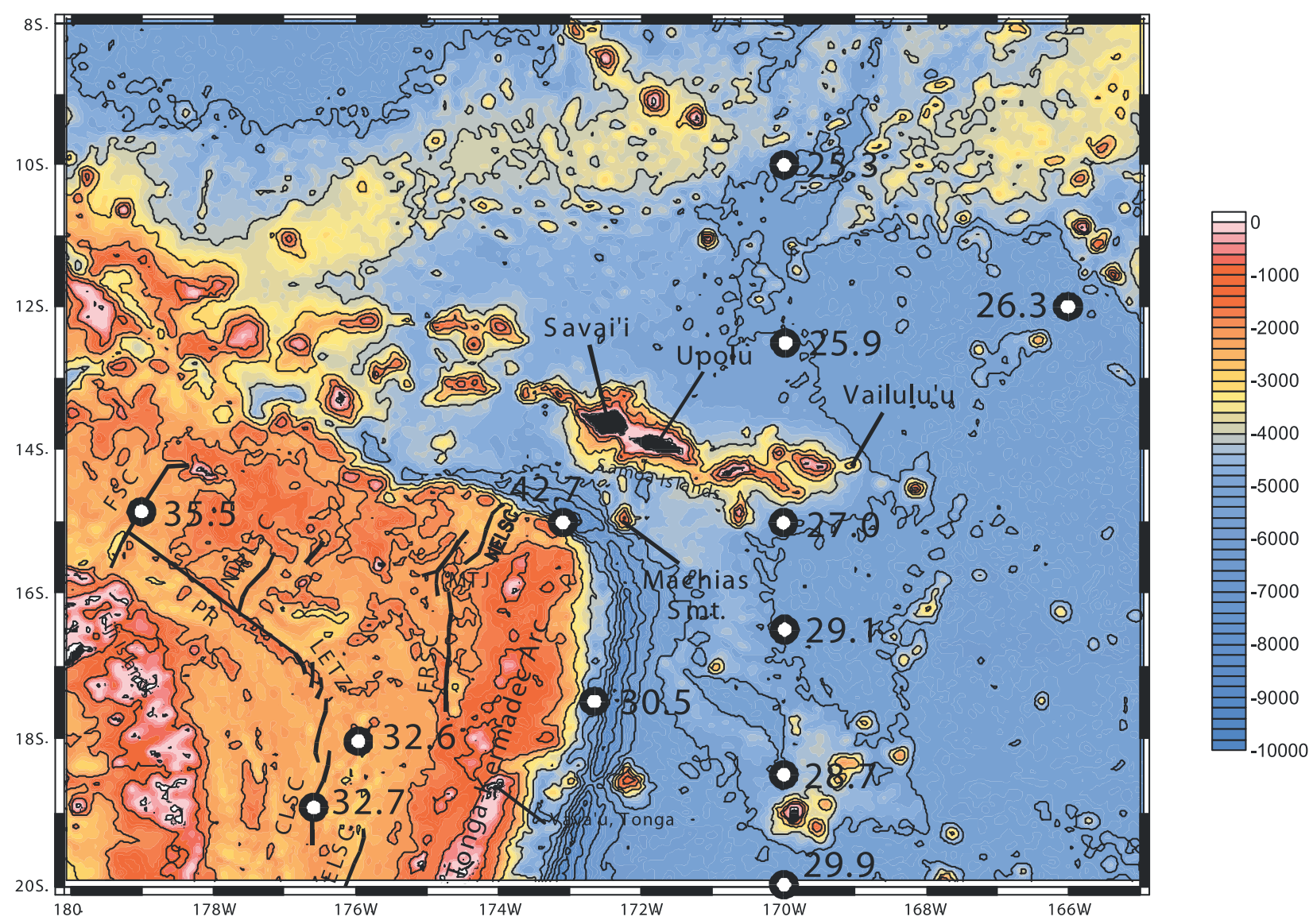

Figure 9. Bathymetric map of the Tonga-Fiji region showing possible sources of the helium plume including the Samoa Islands, Vailulu'u, Machias Seamount, the volcanoes of the Tonga-Kermadec Arc, and the associated back-arc spreading centers of the Lau Basin. The open circles denote hydrographic profiles used in this study. The numbers are the $\delta^{3} \mathrm{He}(\%)$ values measured at each location interpolated onto a surface at $1750-\mathrm{m}$ depth. The solid lines denote the major rift zones in the region [see Zellmer and Taylor, 2001; Pelletier et al., 1998, 2001]. Abbreviations are as follows: FSC, Futuna Spreading Center; NWLSC, NW Lau Spreading Center; PR, Peggy Ridge; LETZ, Lau Extensional Transform Zone; CLSC, Central Lau Spreading Center; ELSC, Eastern Lau Spreading Center; FRSC, Fonualei Rift and Spreading Center; MTJ, Mangatolo Triple Junction; NELSC, Northeastern Lau Spreading Center. The bathymetry is from satellite altimetry [Sandwell and Smith, 1997].

[Hart et al., 2000]. The main evidence for hydrothermal activity comes from a water column survey conducted by Hart et al. [2000], in which they circumnavigated the seamount while towing a hydrographic package equipped with sampling bottles and a nephelometer (see Figure 11). The results showed that Vailulu' $u$ is surrounded by a thick "smog layer" of suspended particles occupying the depth interval of $600-800 \mathrm{~m}$, with the strongest particle signal observed on the northeast and southeast quadrants. Shore-based analysis of discrete water samples collected on the same tow found high Mn concentrations associated with the suspended particle concentrations. The depth and lateral distribution of the plumes surrounding Vailulu'u are consistent with the presence of hydrothermal sources within the summit caldera generating plumes that escape into the surrounding water column through the breaches in the crater wall [Hart et al., 2000]. The question remains as to whether there is hydrothermal activity at other locations and depths on the volcano, possibly outside the summit crater. The nephelometer survey conducted by Hart et al. [2000] extended only to 900-m depth, while Vailulu'u has rift zones that extend to 4000-m depth and below (Figure 10). Thus it is possible that Vailulu'u has undetected hydrothermal sources on its flanks. 


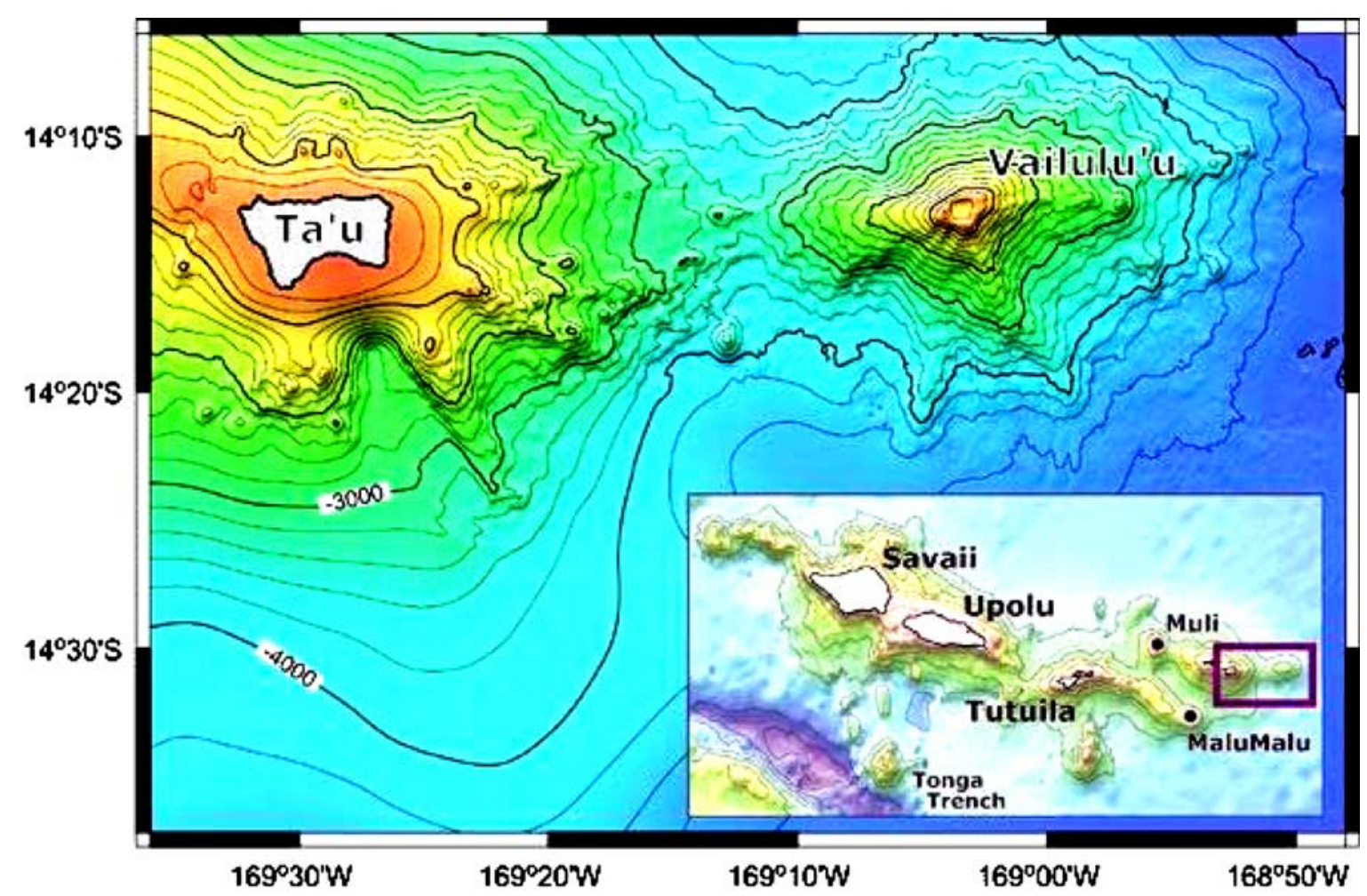

Figure 10. Bathymetric map showing the seamount Vailulu'u in relation to Ta'u and the other Samoa Islands. From Hart et al. [2000].

[17] Vailulu'u has a distinct hydrothermal plume surrounding its summit that is confined to depths of 600 to $800 \mathrm{~m}$ [Hart et al., 2000], almost $1000 \mathrm{~m}$ shallower than the 1750-m depth of the Tonga-Fiji helium plume. Because of the density stratification of the oceanic water column and the generally weak vertical mixing, it is virtually impossible for helium or other hydrothermal tracers injected at 700-m depth to migrate to a different density surface $1000 \mathrm{~m}$ deeper. On this basis we conclude that the hydrothermal activity detected within the summit crater of Vailulu'u cannot be responsible for the significantly deeper helium signal that identifies the Tonga-Fiji plume described here. Two helium profiles collected near Vailulu'u provide additional evidence that the seamount is not the source of the Tonga-Fiji plume. Profiles collected about 60 miles southwest of Vailulu'u at $15^{\circ} \mathrm{S}, 170^{\circ} \mathrm{W}$ in 1990 and again in 2001 have a broad maximum in $\delta\left({ }^{3} \mathrm{He}\right)$ at 2500 -m depth (Figures 5 and 9). These profiles show no evidence of a secondary maximum either at $1750-\mathrm{m}$ depth or at the 600 to $800-\mathrm{m}$ depth of Vailulu'u's summit caldera. Furthermore, these two helium profiles are very similar to others sampled in the region east of the Samoa Islands, suggesting that the maximum at 2500-m depth in these profiles is the distal edge of the EPR helium plume and not from a local source. Therefore we conclude that hydrothermal activity on Vailulu'u is localized and does not produce a far-reaching plume either from activity on its summit or from its flanks.

\subsection{Machias Seamount}

[18] Machias Seamount, located about 50 nautical miles east of TEW Station 39, is another volcano that deserves consideration as a source of the Tonga-Fiji plume because of its proximity to the plume core (see Figures 9 and 12). The seamount is located on the Pacific Plate near the northern end of the Tonga Trench and rises to an elevation of about 1000-m below sea level. Thus Machias is an impressive volcanic edifice situated on seafloor that averages $\sim 4500-\mathrm{m}$ depth [Wright et al., 2000]. A recent bathymetry compilation by Zellmer and Taylor [2000] places the summit at about 700-m depth (see Figure 12). The seamount 
Geochemistry
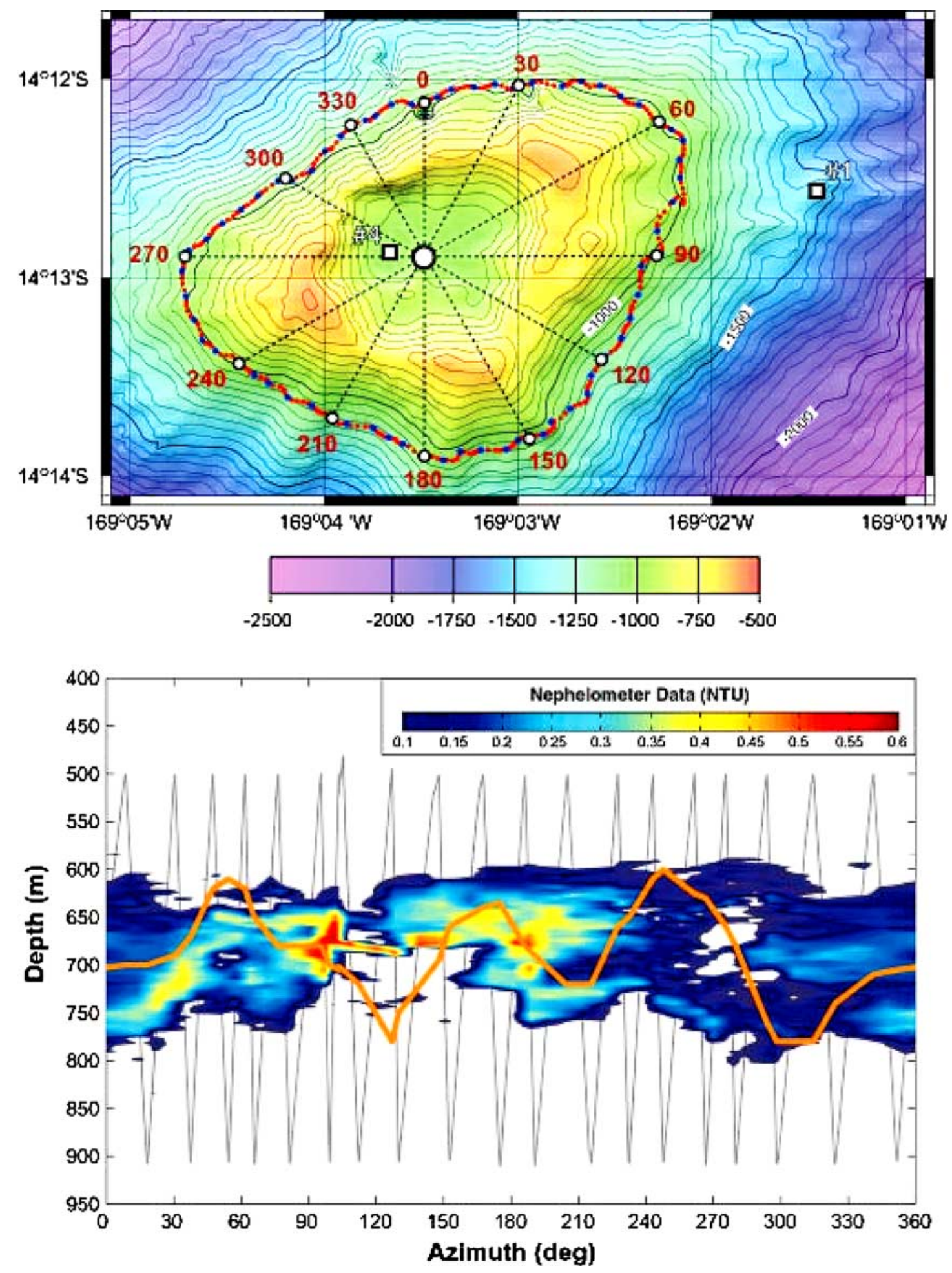

Figure 11. Results of a hydrographic survey around Vailulu'u conducted by Hart et al. [2000]. Upper panel is a map showing the track of their hydrographic tow that circumnavigated the seamount. The lower panel shows the suspended particle plumes detected with a nephelometer during the tow-yo survey. The heavy orange line denotes the height of the summit crater rim. Both figures reproduced from Hart et al. [2000]. 
Geochemistry

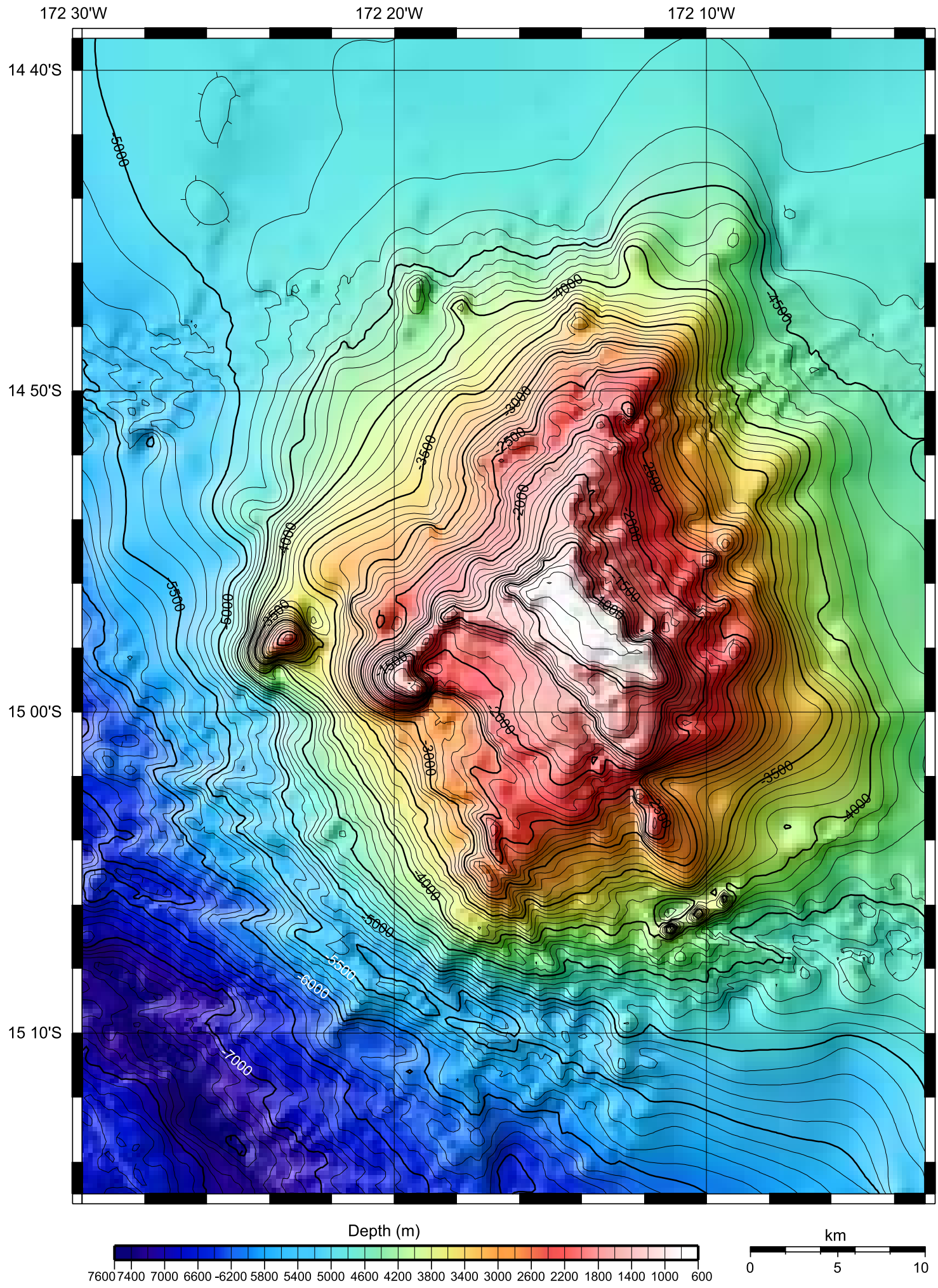

Figure 12. Bathymetric map of Machias Seamount. Bathymetry grid from Zellmer and Taylor [2001]. 
has been dredged by Hawkins and Natland [1975] and by Sharaskin et al. [1983]. Hawkins and Natland [1975] reported the presence of cobbles, gravel, and coral in samples dredged from the summit, indicating that the crest of the seamount was formerly at or above sea level. There were no indications of hydrothermal activity or fresh volcanic rocks in any of the dredges, and a K-Ar age date on a phonolite dredged from the summit suggests activity at $\sim 940,000$ years [Hawkins and Natland, 1975].

[19] As with Vailulu'u, in order for Machias Seamount to be the source of the Tonga-Fiji plume, hydrothermal activity would have to be present quite far down on the flanks of the volcano, since the summit is much shallower than the $1750-\mathrm{m}$ depth of the plume. A recent survey of submarine volcanoes along the southern Kermadec Arc found that hydrothermal activity was almost entirely restricted to the summits of the arc volcanoes, suggesting that flank activity is unlikely [de Ronde et al., 2001]. However, Machias Seamount has been interpreted to be part of the Samoan hotspot chain rather than an arc volcano [Hawkins and Natland, 1975], making it more likely that it might be hydrothermally active at a deep site on one of its rift zones.

\subsection{Volcanoes of the Tonga-Kermadec Arc}

[20] The northern end of the Tonga-Kermadec Arc is very close to the core of the Tonga-Fiji plume, and therefore the arc volcanoes themselves must be considered as a possible source of the plume (Figure 9). The southern end of the Tonga-Kermadec Arc was surveyed in some detail by de Ronde et al. [2001], who detected hydrothermal activity on about half of the submarine volcanoes in that region. Although it is not clear whether this relatively high percentage of activity also applies to the northern part of the arc, it is likely that several of the volcanoes at the northern end of the arc are hydrothermally active. However, like Vailulu'u and Machias Seamount, essentially all of the volcanoes along the northern Tonga-Kermadec Arc rise to depths shallower than $1200 \mathrm{~m}$, making it unlikely that they are the source of the Tonga-Fiji plume (see Figure 9). Furthermore, as mentioned above, de Ronde et al. [2001] found that hydrothermal activity on the southern Kermadec Arc is almost entirely confined to the crest of each volcano. This finding casts further doubt on the Tonga-Kermadec Arc as the source of the Tonga-Fiji hydrothermal plume.

\subsection{The Lau Spreading Center}

[21] The Lau Back-Arc Basin is a complex region of crustal extension located to the west of the Tonga-Kermadec Arc [Hawkins, 1995; Zellmer and Taylor, 2001]. At the southern end of this region, the locus of extension is a linear spreading ridge known either as the Valu Fa Ridge or further north as the Eastern Lau Spreading Center (ELSC) (Figure 9). At about $19.4^{\circ} \mathrm{S}$ the axis of spreading is offset to the west about 35 nautical miles, marking the southern end of the Central Lau Spreading Center (CLSC). At $18.3^{\circ} \mathrm{S}$ the CLSC transitions into a series of short offset spreading segments called the Lau Extensional Transform Zone (LETZ), which in turn transitions into a long transform fault named the Peggy Ridge (PR) (Figure 9). To the north of the CLSC and the Peggy Ridge, the back-arc extension is accommodated on at least 3 different spreading centers, including the Fonualei Rift and Spreading Center (FRSC) and Mangatolo Triple Junction (MTJ), the Northwest Lau Spreading Center (NWLSC), and the Futuna Spreading Center (FSC).

[22] Several active hydrothermal sites have been found and studied on the Valu Fa Ridge and on the CLSC. These include the Hine Hina, Vai Lili, and White Church hydrothermal fields in the region from 21.9 to $22.7^{\circ} \mathrm{S}$ [von Stackelberg et al., 1985; Bortnikov et al., 1993; Fouquet et al., 1993; Herzig et al., 1993]. While the Hine Hina and White Church hydrothermal systems were reported to have low-temperature diffuse venting, the Vai Lili field at 1700 to $1740-\mathrm{m}$ depth has white and black smokers venting fluids up to $342^{\circ} \mathrm{C}$ [Fouquet et al., 1993; Herzig et al., 1993]. In 1982, the R/V S.P. Lee conducted a survey of the Valu Fa Ridge that included seismic profiling and sampling of the water column [Morton et al., 1994]. Two helium profiles collected during the S.P. Lee cruise found a maximum of $\delta^{3} \mathrm{He}=38.7 \%$ at $1827-\mathrm{m}$ depth for 
Station H1 $\left(22^{\circ} 19.3^{\prime} \mathrm{S}, 176^{\circ} 38.8^{\prime} \mathrm{W}\right)$ and $32.0 \%$ at $1824-\mathrm{m}$ depth for Station $\mathrm{H} 2{ }^{\circ}\left(21^{\circ} 55.9^{\prime} \mathrm{S}\right.$, $\left.178^{\circ} 13 \cdot 2^{\prime} \mathrm{W}\right)$. Comparison with the reported locations of the hydrothermal fields discovered later indicates that Station $\mathrm{H} 1$ was situated roughly midway between the Vai Lili and Hine Hina fields, while Station $\mathrm{H} 2$ was positioned very close to the White Church hydrothermal site. Of more relevance to the present study, several hydrographic profiles were completed along the Central Lau Spreading Center in 1986 as part of Papatua Expedition [Craig and Poreda, 1987; Craig et al., 1987]. Two of these profiles were analyzed for helium isotopes and showed $\delta^{3} \mathrm{He}$ increasing to a maximum of about $32-37 \%$ below $1850-\mathrm{m}$ depth. In particular, Papatua Station 5-2, located on the CLSC axis at $18^{\circ} 57.8^{\prime} \mathrm{S}, 176^{\circ} 33.6^{\prime} \mathrm{W}$, reached a maximum $\delta^{3} \mathrm{He}$ of $37.2 \%$ at $2070-\mathrm{m}$ depth. Station 5-3, positioned slightly east of the spreading axis at $18^{\circ} 04.7^{\prime} \mathrm{S}, 175^{\circ} 58.9^{\prime} \mathrm{W}$, had a maximum $\delta^{3} \mathrm{He}=32.7 \%$ at $1854-\mathrm{m}$ depth $(\mathrm{H}$. Craig, private communication, 2001). Excess methane was also observed in several of the Papatua Expedition profiles collected in the Lau Basin. However, Craig et al. [1987] reported that the methane was uncorrelated with the ${ }^{3} \mathrm{He}$ signal, suggesting that it was not hydrothermal in origin.

[23] Although the Lau Basin south of $18^{\circ} \mathrm{S}$ is clearly host to hydrothermal activity that produces water column ${ }^{3} \mathrm{He}$ plumes, it is not likely that this activity is responsible for the Tonga-Fiji plume we have observed farther north. We base this conclusion mainly on the fact that the maximum $\delta^{3} \mathrm{He}$ values reported for the Valu Fa Ridge or the CLSC fall in the range of 32 to $39 \%$, less than the $\delta^{3} \mathrm{He}=42.7 \%$ we observed in the Tonga-Fiji plume at the northern end of the Kermadec Arc. Since dilution due to mixing would reduce the strength of the ${ }^{3} \mathrm{He}$ signal as it is advected northward from the Valu Fa Ridge or CLSC, it seems unlikely that the Lau Basin could produce the strong ${ }^{3} \mathrm{He}$ signal we observed at $15^{\circ} \mathrm{S}$. Secondly, all of the Lau Basin profiles reported increase smoothly toward the bottom reaching a maximum in $\delta^{3} \mathrm{He}$ at depths below $1850 \mathrm{~m}$. In contrast, the Tonga-Fiji plume exhibits a sharp maximum at depths of 1480 to $1726 \mathrm{~m}$ (Figure 1).
It is possible that the shallow topography that intervenes between the Lau Basin and northern end of the Kermadec Arc truncates the deeper part of the helium signal from the Lau Basin. Figure 9 shows quite clearly that when the Papatua Expedition $\delta^{3} \mathrm{He}$ profiles are interpolated onto a $1750-\mathrm{m}$ depth surface, the resulting $\delta^{3} \mathrm{He}$ is only about $32.6 \%$. Thus the fact remains that the Lau Basin ${ }^{3} \mathrm{He}$ signal is too weak and too distant to have produced the $\delta^{3} \mathrm{He}=35-43 \%$ at 1500 to $1750-\mathrm{m}$ depth observed in the Tonga-Fiji plume.

\subsection{Spreading Centers of the Northern Lau Basin}

[24] The extensional zones of the northern Lau region are of particular interest because of their proximity to the region occupied by the Tonga-Fiji plume. Extensional tectonics in the northern Lau province is divided between three zones of spreading: the Futuna Spreading Center (FSC), the Northwest Lau Spreading Center (NWLSC), and the Mangatolo Triple Junction (MTJ) (Figure 9). Any or all of these extensional zones could be host to hydrothermal activity contributing to the TongaFiji plume.

[25] The NWLSC is unsurveyed and no hydrocast data exist for this rift. Pelletier et al. [2001] recently mapped the Futuna Spreading Center, although their survey did not reveal evidence for hydrothermal activity. Pelletier et al. [2001] reported that the active zone of the FSC varies from $600-\mathrm{m}$ depth at its northern end at $14^{\circ} \mathrm{S}$ down to $3739-\mathrm{m}$ depth at its southern end at $15.5^{\circ} \mathrm{S}$. Near $15^{\circ} \mathrm{S}, 179.0^{\circ} \mathrm{W}$ the FSC axis is about 1400 to 1800 $\mathrm{m}$ deep. It is noteworthy that the profile from TEW Station $46\left(14.9^{\circ} \mathrm{S}, 179.0^{\circ} \mathrm{W}\right)$ which has $\delta\left({ }^{3} \mathrm{He}\right)=$ $41.2 \%$ at $1480-\mathrm{m}$ depth (Figure 1) was positioned directly on the axis of the Futuna Spreading Center. This suggests that all or part of the strong ${ }^{3} \mathrm{He}$ signal in this area may be the result of local hydrothermal activity on the Futuna Spreading Center. However, the higher $\delta\left({ }^{3} \mathrm{He}\right)$ signal to the east must have an additional input since our present constraints on the Tonga-Fiji plume distribution and the prevailing currents suggest a plume should advect in a northwesterly direction away from the FSC. 
[26] In the northeastern section of the Lau region, the Mangatolo Triple Junction forms a complex plate boundary connecting to the Fornualei Rift and Spreading Center to the south and to another rift zone to the northeast, sometimes called the Northeast Lau Spreading Center (NELSC) [Pelletier et al., 2001] (Figure 9). In their kinematic model for the opening of the Lau Basin, Zellmer and Taylor [2001] estimate the rate of extension on the MTJ system to be about $9 \mathrm{~cm} / \mathrm{yr}$, faster than the $6.5 \mathrm{~cm} / \mathrm{yr}$ estimated for the Valu Fa Ridge farther south. This triple rift system is almost directly beneath the core of the Tonga-Fiji water column plume and therefore particularly intriguing as its likely source. In fact, an extinct black smoker chimney with polymetallic sulfides was dredged from 2100-m depth from the MTJ in 1986, clear evidence for past hydrothermal activity [Hawkins, 1986; Hawkins and Helu, 1986]. Although the water depth of the extinct sulfides is perhaps too great to have produced the Tonga-Fiji plume, parts of the MTJ system are situated at depths of $1500-$ $1900 \mathrm{~m}$, appropriate for the generation of the Tonga-Fiji plume [Zellmer and Taylor, 2001]. Given the relatively high spreading rate of the Mangatolo Triple Junction, combined with its proximity to the core of the Tonga-Fiji plume, we conclude that this extensional system may be responsible for all or part of the plume signal we have described above.

\section{Summary and Conclusions}

[27] We have detected a water column hydrothermal plume in the Tonga-Fiji region of the south Pacific based on the distribution of excess ${ }^{3} \mathrm{He}$ in hydrographic profiles. The strongest expression of the plume is at $15^{\circ} \mathrm{S}, 173^{\circ} \mathrm{W}$ at the northern end of the Tonga-Kermadec Arc. In this profile $\delta\left({ }^{3} \mathrm{He}\right)$ reaches a sharp maximum of $43.4 \%$ at a depth of $1726 \mathrm{~m}$. This magnitude of ${ }^{3} \mathrm{He}$ enrichment is typically observed only over the axis of active mid-ocean ridge spreading centers. However, this profile was positioned in deep water $(>5000 \mathrm{~m})$ in the bathymetric gap between the Samoa Islands and the northern end of the Tonga-Kermadec Arc, not clearly associated with any active volcanoes or rift zones. A second profile at $14.9^{\circ} \mathrm{S}, 179^{\circ} \mathrm{W}$, about $650 \mathrm{~km}$ farther west, showed similarly strong ${ }^{3} \mathrm{He}$ enrichment. However, this second profile was by chance positioned directly on the axis of the Futuna Spreading Center, and the ${ }^{3} \mathrm{He}$ may be due to local hydrothermal sources on the FSC.

[28] We conclude that the ${ }^{3} \mathrm{He}$ signal at $15^{\circ} \mathrm{S}$, $173^{\circ} \mathrm{W}$ represents a hydrothermal plume that was advected to this location from a strong source nearby. The fact that the Tonga-Fiji plume is much shallower than typical plumes generated on midocean ridges eliminates the East Pacific Rise and the Pacific-Antarctic Ridge as possible sources. We have mapped the areal extent of the plume by carefully interpolating all available $\delta\left({ }^{3} \mathrm{He}\right)$ values onto a surface at $1750-\mathrm{m}$ depth. These data show that the plume is truncated quite rapidly to the east, but appears to be carried to the north and west from the Tonga-Fiji region, suggesting that the plume can be traced as a continuous signal as far away as the Coral Sea $\sim 3800 \mathrm{~km}$ west of Samoa. This distribution is in agreement with the best estimates of the regional geostrophic flow which describes a general northwesterly water transport across the northern end of the Kermadec Arc at 1500 to 2000-m depth [Reid, 1997].

[29] Unfortunately we do not have enough hydrographic coverage in this region to confidently identify the source of the plume. On the basis of our knowledge of the behavior of ascending buoyant plumes, we conclude that the source must be situated at about 1750 to $2000-\mathrm{m}$ depth in order to produce the observed plume signal at $1726-\mathrm{m}$ depth. This constraint eliminates many potential sources in the region. For example, Vailulu'u and Machias Seamount are possible sources, but both volcanoes are too shallow to have produced the Tonga-Fiji plume unless they have active hydrothermal sources on their flanks. In particular, the hydrothermal activity discovered within the summit caldera of Vailulu'u at 600-m depth [Hart et al., 2000] cannot be responsible for the Tonga-Fiji plume because this activity is far too shallow. A similar argument can be used to eliminate the volcanoes of the northern end of the TongaKermadec Arc, all of which are shallower than $1400 \mathrm{~m}$ at their summits. Activity associated with 
the Samoa Islands is also a possibility, but again the activity would have to be on the flanks of one of the volcanic islands. Active hydrothermal venting has been discovered and studied on the southern part of the Lau Basin back-arc spreading system. However, as discussed in the preceding section, the published ${ }^{3} \mathrm{He}$ data for the Lau Basin indicate that the venting on the Valu Fa Ridge and CLSC is too weak and too far away to have produced the Tonga-Fiji plume signal. The most promising sources are the many rift zones of the northern Lau spreading system, namely the Futuna Spreading Center, the Northwest Lau Spreading Center, and the Mangatolo Triple Junction. Specifically, the MTJ and the associated Northeast Lau Spreading Center appear to be prime candidates for the plume source since they are estimated to be spreading at $9 \mathrm{~cm} / \mathrm{yr}$ and are situated only about $130 \mathrm{~km}$ from $15^{\circ} \mathrm{S}, 173^{\circ} \mathrm{W}$ where the strongest $\delta\left({ }^{3} \mathrm{He}\right)$ signal was detected.

[30] Finally, it is appropriate to emphasize the potential this plume represents for studies of ocean mixing and circulation. Very little is known about the specifics of the deep circulation in this region of the Pacific, especially at the 1700-m depth of the Tonga-Fiji plume. Furthermore, as mentioned above, this plume is the strongest hydrothermal feature in the entire Pacific basin at this depth. The deep circulation in this region is of particular interest because the supply of deep water to the entire Pacific basin passes along the eastern margin of the Kermadec Arc on its way north into the central Pacific. If the plume source could be located, then subsequent studies of the distribution of excess ${ }^{3} \mathrm{He}$ would place strong constraints on the regional circulation. We believe that the Tonga-Fiji helium plume merits further study, in terms of both identifying the source of the plume and mapping its areal extent in more detail.

\section{Acknowledgments}

[31] We are indebted to the late Stan Hays and the crew and science party of the NOAA Ship Oceanographer, and John Church, Susan Wijffels, and the science party of the R/V Franklin for collecting helium samples during expeditions TEW and FR05, respectively. The late Harmon Craig kindly provided unpublished helium data from the Papatua Expedition which were used in this study. This paper profited from discussions with James Hawkins, Fernando Martinez, Robert Embley, Ken Farley, Stan Hart, and Hubert Staudigel. Mike Mottl and an anonymous reviewer provided constructive reviews of the paper. We thank Stan Hart for granting us permission to use figures from his paper on Vailulu'u, and Susan Merle for help with several of the figures. In interpolating our data and generating several of the figures we made considerable use of the Ocean Data View software program developed by Reiner Schlitzer, Alfred Wegener Institute for Polar and Marine Research, Bremerhaven, Germany. This work was supported by the NOAA Vents Program and by Grants OCE91-05884, OCE92-96237, OCE92-96169, and OCE98-20132 of the Ocean Sciences Division of the National Science Foundation. This is PMEL Contribution 2593.

\section{References}

Bortnikov, N. S., et al. (1993), Mineral composition and conditions of the formation of sulfide edifices in the Lau Basin (southwestern sector of the Pacific Ocean), Geol. Ore Deposits, 35, 476-488.

Clague, D. A., and G. B. Dalrymple (1989), Tectonics, geochronology, and origin of the Hawaiian-Emperor chain, in The Geology of North America: The Eastern Pacific Ocean and Hawaii, edited by E. L. Winterer, D. M. Hussong, and R. W. Decker, pp. 188-217, Geol. Soc. of Am., Boulder, Colo.

Clarke, W. B., M. A. Beg, and H. Craig (1969), Excess ${ }^{3}$ He in the sea: Evidence for terrestrial primordial helium, Earth Planet. Sci. Lett., 6, 213-220.

Craig, H., and R. Poreda (1987), Data Report, Papatua Expedition Legs V and VI, SIO Ref. Ser., vol. 87-14, Scripps Oceanogr., Univ. of Calif., San Diego.

Craig, H., V. K. Craig, and K.-R. Kim (1987), PAPATUA Expedition I: Hydrothermal vent surveys in back-arc basin: The Lau, N. Fiji, Woodlark, and Manus Basins and Havre Trough (abstract), Eos Trans. AGU, 68, 100.

de Ronde, C. E. J., E. T. Baker, G. J. Massoth, J. E. Lupton, I. C. Wright, R. A. Feely, and R. R. Greene (2001), Intraoceanic subduction-related hydrothermal venting, Kermadec forearc, New Zealand, Earth Planet. Sci. Lett., 193, 359369.

Farley, K. A., and E. Neroda (1998), Noble gases in the earth's mantle, Annu. Rev. Earth Planet. Sci., 26, 189-218.

Farley, K. A., J. H. Natland, and H. Craig (1992), Binary mixing of enriched and undegassed (primitive?) mantle components $(\mathrm{He}, \mathrm{Sr}, \mathrm{Nd}, \mathrm{Pb})$ in Samoan lavas, Earth Planet. Sci. Lett., 111, 325-339.

Fouquet, Y., et al. (1993), Metallogenesis in back-arc environments: The Lau Basin example, Econ. Geol., 88, 21542181.

Hart, S. R., et al. (2000), Vailulu'u undersea volcano: The new Samoa, Geochem. Geophys. Geosyst., 1, Paper number 2000GC000108.

Hawkins, J. W. (1986), "Black Smoker" vent chimneys (abstract), Eos Trans. AGU, 67, 430.

Hawkins, J. W. (1995), Evolution of the Lau Basin: Insights from ODP Leg 135, in Active Margins and Marginal Basins, 
Geophys. Monogr. Ser., vol. 88, edited by B. Taylor and J. Natland, pp. 125-174, AGU, Washington, D.C.

Hawkins, J. W., and S. Helu (1986), Polymetallic sulphide deposit from "black smoker" chimney: Lau Basin (abstract), Eos Trans. AGU, 67, 378.

Hawkins, J. W., and J. H. Natland (1975), Nephelinites and basanites of the Samoan linear volcanic chain: Their possible tectonic significance, Earth Planet. Sci. Lett., 24, 427-439.

Herzig, P., et al. (1993), Gold-rich polymetallic sulfides from the Lau back arc and implications for the geochemistry of gold in sea-floor hydrothermal systems of the Southwest Pacific, Econ. Geol., 88, 2182-2209.

Jenkins, W. J., J. M. Edmond, and J. B. Corliss (1978), Excess ${ }^{3} \mathrm{He}$ and ${ }^{4} \mathrm{He}$ in Galapagos submarine hydrothermal waters, Nature, 272, 156-158.

Krylov, A. Y., B. A. Mamyrin, L. A. Khabarin, T. I. Maxina, and Y. I. Silin (1974), Helium isotopes in ocean floor bedrock, Geokhimiya, 8, 1220-1225.

Lupton, J. E. (1995), Hydrothermal plumes: Near and far field, in Seafloor Hydrothermal Systems: Physical, Chemical, Biological, and Geological Interactions, Geophys. Monogr. Ser., vol. 91, edited by S. Humphris et al., pp. 317-346, AGU, Washington, D. C.

Lupton, J. E. (1996), A far-field hydrothermal plume from Lo'ihi Seamount, Science, 272, 976-979.

Lupton, J. E. (1998), Hydrothermal helium plumes in the Pacific Ocean, J. Geophys. Res., 103, 15,853-15,868.

Lupton, J. E., and H. Craig (1975), Excess ${ }^{3} \mathrm{He}$ in oceanic basalts: Evidence for terrestrial primordial helium, Earth Planet. Sci. Lett., 26, 133-139.

Lupton, J. E., R. F. Weiss, and H. Craig (1977), Mantle helium in hydrothermal plumes in the Galapagos Rift, Nature, 267, $603-604$.

Mangum, L., J. Lynch, K. McTaggart, L. Stratton, and S. Hayes (1991), CTD/O2 data measurements collected on TEW (Transport of Equatorial Waters), June-August 1987, NOAA Data Report ERL PMEL-33, Pacific Mar. Env. Lab., Seattle, Wash.
Morton, J. L., G. J. Massoth, J. E. Lupton, and M. G. Bac (1994), Valu Fa Ridge, Lau Basin: Evidence for hydrothermal circulation (S.P. Lee Cruise L3-84-SP), in Geology and Submarine Resources of the Tonga-Lau-Fiji Region, edited by A. J. Stevenson, R. H. Herzer, and P. F. Ballance, Tech. Bull. 8, pp. 299-306, SOPAC, Fiji.

Pelletier, B., S. Calmant, and R. Pillet (1998), Current tectonics of the Tonga-New Hebrides region, Earth Planet. Sci. Lett., 164, 263-276.

Pelletier, B., Y. Lagabrielle, M. Benoit, G. Cabioch, S. Calmant, E. Garel, and C. Guivel (2001), Newly identified segments of the Pacific-Australia plate boundary along the North Fiji transform zone, Earth Planet. Sci. Lett., 193, 347-358.

Reid, J. L. (1997), On the total geostrophic circulation of the south Pacific Ocean: Flow patterns, tracers and transports, Prog. Oceanogr., 39, 263-352.

Sandwell, D. T., and H. F. W. Smith (1997), Marine gravity anomaly from Geosat and ERS-1 satellite altimetry, J. Geophys. Res., 102, 10,309-10,054.

Sharaskin, A. Y., I. K. Pustchin, S. K. Zlobin, and G. M. Kolesov (1983), Two ophiolite sequences from the basement of the Northern Tonga Arc, Ofioliti, 8, 411-430.

von Stackelberg, U., and Shipboard Scientific Party (1988), Active Hydrothermalism in the Lau Back-Arc Basin (SWPacific): First results from the SONNE 48 Cruise (1987), Mar. Min., 7, 431-442.

Wisegarver, D. P., J. L. Bullister, R. H. Gammon, R. A. Menzia, and K. C. Kelly (1993), NOAA chlorofluorocarbon tracer program air and seawater measurements: 1986-1989, NOAA Data Rep. ERL PMEL-43, Pacific Mar. Env. Lab., Seattle, Wash.

Wright, D. W., S. H. Bloomer, C. J. MacLeod, B. Taylor, and A. M. Goodlife (2000), Bathymetry of the Tonga Trench and forearc: A map series, Mar. Geophys. Res., 21, 489-511.

Zellmer, K., and B. Taylor (2001), A three-plate kinematic model for Lau Basin opening, Geochem. Geophys. Geosyst., 2, Paper number 2000GC000106. 